\title{
PRODUCTION OF ACTINOMYCIN-D BY THE MUTANT OF A NEW ISOLATE OF STREPTOMYCES SINDENENSIS
}

\author{
Vandana Praveen $^{1}$; C.K.M. Tripathi ${ }^{1 *}$; Vinod Bihari ${ }^{1}$; S.C. Srivastava ${ }^{2}$ \\ ${ }^{1}$ Fermentation Technology Division, Central Drug Research Institute, Chattar Manzil, Lucknow-226001, India; ${ }^{2}$ Department of \\ Botany, University of Lucknow, Lucknow- 226001, India.
}

Submitted: August 27, 2007; Returned to authors for corrections: February 05, 2008; Approved: July 06, 2008.

\begin{abstract}
An actinomycin-D producing strain was isolated from soil and characterized as Streptomyces sindenensis. The culture was subjected to UV irradiation and a mutant with $400 \%$ higher actinomycin-D production was isolated (400 mg/ $/ \mathrm{l}^{-1}$ as compared to $80 \mathrm{mg} / \mathrm{l}^{-1}$ produced by the parent). Production medium was optimized and antibiotic yield with the mutant was enhanced to $850 \mathrm{mg} / \mathrm{l}^{-1}$ which is $963 \%$ higher as compared with the parent.
\end{abstract}

Key words: Actinomycin-D, antibiotics, Streptomyces, mutation

The actinomycins are chromopeptide lactone antibiotics, of which more than 30 natives are known. Among the actinomycins, actinomycin-D (act-D) has been studied extensively and is used clinically for the treatment of Wilms' tumor (3). Various strains of Streptomyces and Micromonospora are reported to produce different forms of actinomycins (9). Production and optimization of act-D by $S$. sindenensis is not reported in literature. Present study reports isolation of a high yielding mutant of $S$. sindenensis for the production of act-D. Bioprocess parameters for the mutant cultivation and optimum product formation were studied.

The producer microorganism, designated as C-5, was isolated from the soil sample, collected from steel plant effluents (Barabanki, U.P., India) and maintained on ISP-2 (International Streptomyces Project) agar slants containing glucose $4 \mathrm{~g}$, yeast extract $4 \mathrm{~g}$, malt extract $10 \mathrm{~g}, \mathrm{CaCO}_{3} 2 \mathrm{~g}$, agar $20 \mathrm{~g}$ and distilled water $1 \mathrm{~L}, \mathrm{pH}$ adjusted to 7-7.2 before sterilization. Morphological and cultural characteristics were studied using the ISP media recommended by Shirling and Gottlieb, 1966(11). For Scanning Electron Microscopy (SEM) samples were prepared according to the methods described by Castillo et al. (2). The strain was characterized as $S$. sindenensis by $16 \mathrm{~S}$ rRNA homology (data not shown) and has been deposited at MTCC (www.http:// mtcc.imtech.res.in), Chandigarh, India (MTCC 8122). Nearly complete (1366 bp) 16S rRNA sequence of strain has been submitted in the NCBI Gen Bank database (accession number EF422787).

Antibiotic production was studied in shake flask with the production medium containing: soy bean meal $10 \mathrm{~g}$, glycerol $15 \mathrm{ml}, \mathrm{MgSO}_{4} .7 \mathrm{H}_{2} \mathrm{O} 0.5 \mathrm{~g},\left(\mathrm{NH}_{4}\right)_{2} \mathrm{HPO}_{4} 0.5 \mathrm{~g}, \mathrm{~K}_{2} \mathrm{HPO}_{4} 1.0 \mathrm{~g}, \mathrm{NaCl}$ $3 \mathrm{~g}, \mathrm{CaCO}_{3} 2 \mathrm{~g}$, and distilled water $1 \mathrm{~L}, \mathrm{pH}$ adjusted to 7-7.2 before sterilization in autoclave at $15 \mathrm{lb}$ PS i (1 Kg PS cm) for 15 minutes. Seed culture was prepared in $250 \mathrm{ml}$ Erlenmeyer flask containing $50 \mathrm{ml}$ of production medium by inoculating a loop full culture from the slant and incubating at $28^{\circ} \mathrm{C}$ on rotary shakers at $200 \mathrm{rpm}$ for $48 \mathrm{~h}$. Antibiotic production was observed in the same medium by inoculating $1 \mathrm{~L}$ flask ( $200 \mathrm{ml}$ medium) with $2.5 \%(\mathrm{v} / \mathrm{v})$ of seed culture and growing under the same conditions for $168 \mathrm{~h}$. Fermented broth was centrifuged and supernatant was extracted thrice with ethyl acetate, filtered and concentrated invaccuo. Antibiotic titer was estimated by the Reverse phase HPLC with ODS-3 column (outer dia.., $250 \mathrm{x}$ $6.35 \mathrm{~mm}$ ) with a particle size of $10 \mu$ and Lambda-Max Spectrophotometer- LC 481 variable wavelength detector 254 $\mathrm{nm}$, at a flow rate of $0.6 \mathrm{ml} / \mathrm{min}$. with acetonirile:water $(55: 45)$ as eluting solvent. Act-D was eluted at 21.4 min retention time. Unless otherwise stated, all the chemicals and media components were purchased from Hi-media labs, Mumbai, India.

*Corresponding Author. Mailing address: Fermentation Technology Division, Central Drug Research Institute, Chattar Manzil, Lucknow-226001, India. Fax: 0522-2623938. E-mail: ckmtcdri@yahoo.com 
Bacillus subtilis ATCC 6633 was used as the test strain for the bioassay of antibiotic production.

Spores of S. sindenensis were gently scrapped from the surface of ISP-2 agar plates, washed with sterile normal saline $(0.85 \%)$ and filtered through glass wool. Spore suspension was diluted to have a count of $10^{4} / \mathrm{ml}$ as, determined by the viability observed on ISP-2 agar plate. Three $\mathrm{ml}$ of spore suspension was irradiated for $30 \mathrm{~min}$. with a UV lamp $(254 \mathrm{~nm})$ placed about $30 \mathrm{~cm}$ above from the liquid surface and gently swirled (magnetically with a needle) in a Petri dish (covered by a piece of dialyzing membrane). Following irradiation, spores were kept in dark at $4^{\circ} \mathrm{C}$ overnight.

Rifampicin (Rf) and streptomycin (S) were used as screening agents for identification of mutants among the survivors. After incubation in dark, spores were plated in triplicates on ISP-2 agar plates containing $25 \mu \mathrm{g} \mathrm{ml}^{-1}$ of S and Rf each, incubated at $28^{\circ} \mathrm{C}$ and observed after $48 \mathrm{hr}$. Mutant colonies with different morphology and expressing, successively, resistance to $\mathrm{S}$ and $\mathrm{Rf}$ were isolated. Antibiotic production by mutants was studied with $10 \mu \mathrm{g} \mathrm{ml}^{-1}$ of S and Rf added in shake flasks. Parallel control flasks were also run for the parent culture. Confirmation for improved antibiotic production was done in shake flasks with no addition of $\mathrm{S}$ and Rf.

Effects of different carbon and nitrogen sources on antibiotic production were evaluated for medium optimization (Table 1). Glycerol was replaced with different sugars (1\%). Amino acids were supplemented to complete production medium $(0.1 \%)$. Mutant was cultivated in optimized medium using NBS BioFlow 110 bench top stirred bioreactor.

The rate of survival of UV irradiated cell progenies was $1 \%$. Fifty colonies, showing resistance for higher concentration of $\mathrm{Rf}$ and $\mathrm{S}\left(25 \mu \mathrm{g} \mathrm{ml}^{-1}\right.$ each $)$ and higher zone of inhibition against B. subtilis were selected for further studies. One such mutant designated as M-46, produced 5 folds higher act-D $\left(400 \mathrm{mg} / \mathrm{l}^{-1}\right)$ as compared to the parent strain $\left(80 \mathrm{mg} / \mathrm{l}^{-1}\right)$.

The parent and M-46 were studied for their cultural characteristics with respect to the utilization of nitrate, urea and sodium citrate. M-46 utilized Sodium citrate while the parent did not. M-46 better utilized other substrates (starch, asparagine, yeast extract and tyrosine) as evidenced by the colony size and pigment production. Growth of parent and M-46 was also observed on medium ISP 2 - 7 media. The parent strain did not produce melanin on ISP-6 agar where as M-46 produced brown color indicating the production of melanin. On ISP-2 agar plates, M-46 showed vigorous sporulation and higher pigment production. As shown in SEM images (Fig. 1) M-46 spores were stouter $(0.7 \times 0.5 \mu \mathrm{m})$ as compared to spores produced by the parent strain $(0.7 \times 0.3 \mu \mathrm{m})$.

Influence of different carbon and nitrogen sources on act-D production by parent strain and M-46 is given in Table 1. Most of the medium components that favoured act-D production by the parent strain also favoured mutant. It is evidenced from Fig. $1(\mathrm{C} \& \mathrm{D})$ that act-D production by the mutant was enhanced.
Negative effect exerted by glutamate and aspartic acid (29 and $45 \%$ decreased production) on antibiotic production by the mutant was the only contradiction observed. Replacement of glycerol with fructose gave an enhancement of 65 and $138 \%$ in the antibiotic titer of M-46 and parent strain respectively (Table 1). Incorporation of DL-threonine in the production medium also favoured act-D production by the mutant as well as parent strain (55 and 57\% respectively). Finally a production medium containing: soy bean meal $10 \mathrm{~g}$, fructose $15 \mathrm{~g}$, DL-threonine $1 \mathrm{~g}$, $\mathrm{MgSO}_{4} .7 \mathrm{H}_{2} \mathrm{O} 0.5 \mathrm{~g},\left(\mathrm{NH}_{4}\right)_{2} \mathrm{HPO}_{4} 0.5 \mathrm{~g}, \mathrm{~K}_{2} \mathrm{HPO}_{4} 1.0 \mathrm{~g}, \mathrm{NaCl} 3 \mathrm{~g}$, $\mathrm{CaCO}_{3} 2 \mathrm{~g}$, and distilled water $1 \mathrm{~L}$, $\mathrm{pH}$ adjusted to 7-7.2, was used for act-D production by M-46 giving an enhancement of $77 \%$ $\left(710 \mathrm{mg} / \mathrm{l}^{-1}\right)$ as compared to the yield obtained with M-46 in normal production medium. When M-46 was cultivated in stirred bioreactor with aeration and agitation rates of $1.5 \mathrm{vvm}$ and 600 $\mathrm{rpm}$ respectively, productivity was enhanced by $963 \%(850$ $\left.\mathrm{mg} / \mathrm{l}^{-1}\right)$ as compared to the parent strain, cultivated in shake flasks with non-optimized medium $\left(80 \mathrm{mg} / \mathrm{l}^{-1}\right)$.

In our study, we have observed an enhancement in act-D synthesis by the introduction of Rifampicin and Streptomycin resistance into $S$. sindenensis. Introduction of certain mutations into rpo gene that confer resistance to Rifampicin are reported to activate the antibiotic production by Streptomyces spp. (5).

Table 1. Influence of C \& N sources on act-D production by parent and mutant.

$$
\begin{array}{lcc}
\text { C \& N sources cell weight, } & \text { act-D, } \\
\mathrm{g} \mathrm{l}^{-1} & \mathrm{mg} \mathrm{l}^{-1}
\end{array}
$$

parent M-46 parent M-46

\begin{tabular}{lcccc}
\hline \multicolumn{2}{l}{ replacement of glycerol with (1\%) } & \multicolumn{3}{l}{} \\
fructose & 7.2 & 6.2 & 190 & 660 \\
lactose & 6.8 & 6.0 & 156 & 510 \\
maltose & 7.0 & 6.0 & 130 & 590 \\
mannose & 7.5 & 7.0 & 70 & 369 \\
xylose & 7.5 & 6.2 & 110 & 480 \\
production medium & 7.0 & 6.1 & 80 & 400 \\
supplimentation of production & medium & with & $(0.1 \%)$ & \\
L-asparagine monohydrate & 6.8 & 6.0 & 66 & 440 \\
DL-aspartic acid & 7.5 & 6.2 & 148 & 220 \\
L-glutmate & 7.0 & 5.5 & 141 & 284 \\
L-histidine & 6.8 & 6.0 & 110 & 335 \\
Hydroxy L-proline & 6.9 & 6.5 & 90 & 330 \\
DL-isoleucine & 6.8 & 7.2 & 88 & 286 \\
DL-serine & 6.8 & 6.0 & 64 & 266 \\
DL-threonine & 7.2 & 6.5 & 126 & 620 \\
L-tryptophan & 7.5 & 6.2 & 74 & 438 \\
Optimized medium & 6.8 & 6.2 & 215 & 710 \\
Optimized medium (bioreactor) & 7.0 & 6.8 & 270 & 850 \\
\hline
\end{tabular}




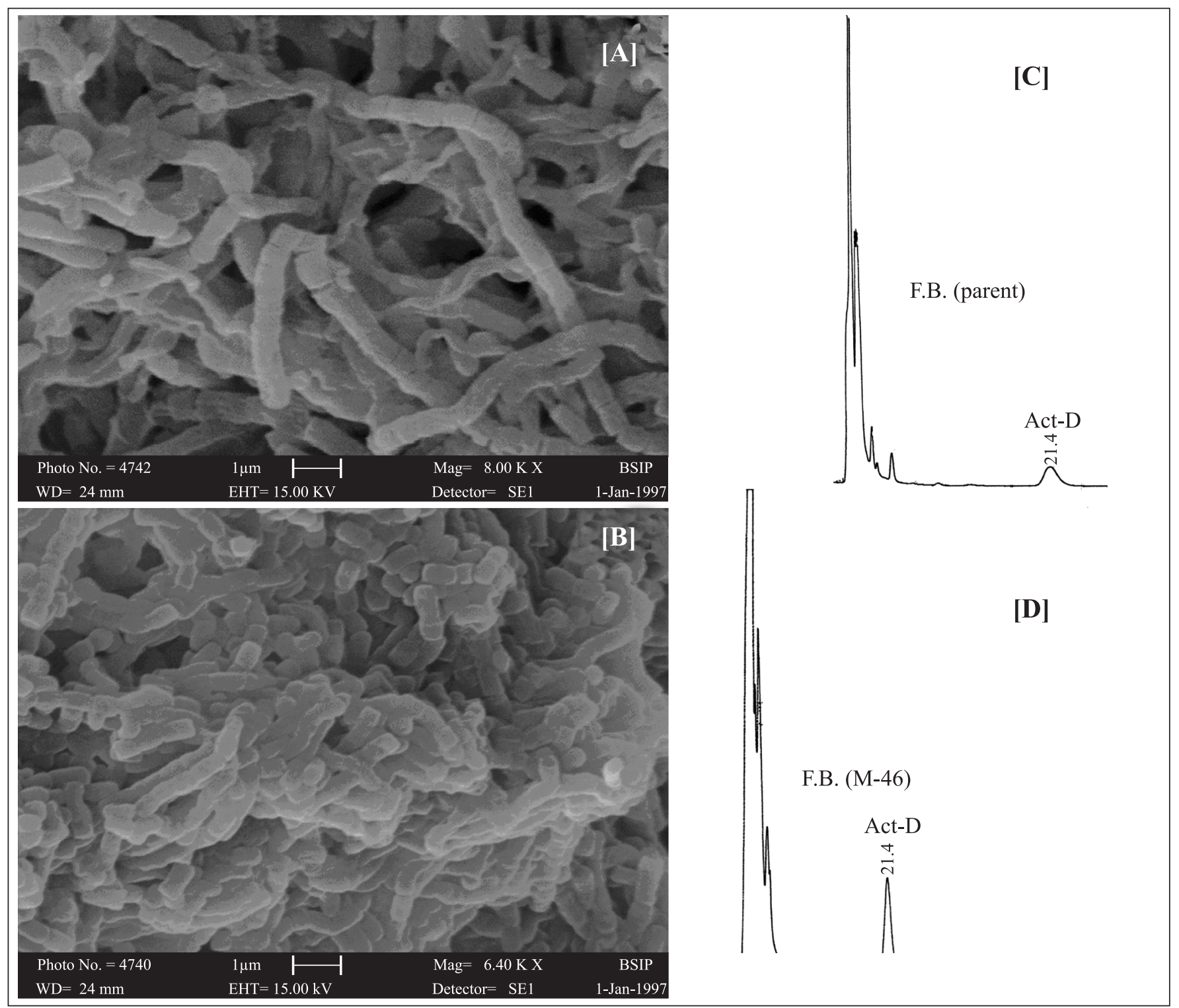

Figure 1. A \& B, showing SEM images of parent and mutant strain and C \& D showing the HPLC profile of fermented broth (F.B.) of parent and mutant strains respectively.

DNA-dependent RNA polymerase (RNAP), which is composed of an essential catalytic core enzyme $\left(\alpha_{2} \beta \beta \omega\right)$ and one of the sigma $(\sigma)$ factors, is the central enzyme for the expression of genomic information in all organisms. Rifampicin (Rif) inhibits transcription initiation by blocking the subunit of bacterial RNA Polymerase (7). Resistance to streptomycin is brought about by mutation in the rps $L$ gene which encodes for the $\mathrm{S} 12$ protein of the $30 \mathrm{~S}$ subunit of the ribosome (10).

In our studies, fructose was found to induce a substantial increase in act-D production by the mutant and parent both. Inbar and Lipidot (6) showed that carbon atoms of an intracellular glutamate pool of $S$. parvullus were not derived biosynthetically from the culture medium glutamate source but rather from fructose catabolism. Foster and Katz (4) found that in case of S. parvullus use of L-glutamate and L-aspartate as a $\mathrm{C}$-source exerts catabolic repression on synthesis of tryptophan oxygenase, an enzyme needed for the synthesis of actinomycin. Perhaps in case of M-46 this catabolic repression has got expressed at a higher level as L-glutamate and DL-aspartic acid supplementations were found to inhibit the production of actD significantly (29 and $45 \%$ respectively). Some nitrogen sources may get incorporated in antibiotic molecules as 
precursors or their amino groups transfer to specific intermediate products (1). Katz and Goss (8) have reported up to $83 \%$ enhancement in act-D production by $S$. chrysomallus with the addition of DL-valine in the production medium. In our studies, positive effects of DL-threonine, L-valine and proline could be due to their direct incorporation in the peptide chains attached to the chromophore (actinocin) of act-D molecule.

\section{ACKNOWLEDGEMENT}

This study was financially supported by Council of Scientific and Industrial Research, India.

\section{RESUMO}

\section{Produção de actinomicina-D por um mutante de uma nova cepa de Streptomyces sindenensis}

Uma cepa produtora de actinomicina-D foi isolada de solo e caracterizada como Streptomyces sindenensis. A cultura foi submetida à radiação UV, e um mutante capaz de produzir $400 \%$ mais actinomicina-D foi isolado $(400 \mathrm{mg} / \mathrm{L}$ comparado a $80 \mathrm{mg} / \mathrm{L}$ produzido pela cepa parental). O meio de produção do antibiótico foi otimizado e o rendimento aumentou para $850 \mathrm{mg} / \mathrm{L}$, ou seja, $963 \%$ mais alto que a cepa parental.

Palavras-chave: actinomicina-D, antibióticos, Streptomyces, mutação

\section{REFERENCES}

1. Aharonowitz, Y. (1980). Nitrogen metabolite regulation of antibiotic biosynthesis. Ann. Rev. Microbiol., 34, 209-234.

2. Castillo, U.F.; Strobel, G.A.; Ford, E.J.; Hess, W.M.; Porter, H.; Jensen, J.B.; Albert, H.; Robison, R.; Condron, M.A.; Teplow, D.B.; Stevens, D.; Yaver, D. (2002). Munumbicins, wide-spectrum antibiotics produced by Streptomyces NRRL 30562, endophytic on Kennedia nigriscans. Microbiology, 148, 2675-2685.

3. Farber, S.; D'Angio, G.; Evans, A.; Mitus, A. (2002). Clinical studies of actinomycin D with special reference to Wilms' tumor in children. 1960. J. Urol., 168, 2560-2562.

4. Foster, J.W.; Katz, E. (1981). Control of actinomycin D biosynthesis n Streptomyces parvullus: Regulation of tryptophan oxygenase activity. J. Bacteriol., 148, 670-677.

5. Hu, H.; Ochi, K. (2001). Novel approach for improving the productivity of antibiotic-producing strains by inducing combined resistant mutations. Appl. Environtl. Microbiol., 6, 1885-1892.

6. Inbar, I.; Lapidot, A. (1988). Metabolic regulation in Streptomyces parvulus during actinomycin $\mathrm{D}$ synthesis, studied with ${ }^{13} \mathrm{C}$ - and ${ }^{15} \mathrm{~N}$ labeled precursors by ${ }^{13} \mathrm{C}$ and ${ }^{15} \mathrm{~N}$ nuclear magnetic resonance spectroscopy and by gas chromatography-mass spectrometry. $J$. Bacteriol., 170, 4055-4064.

7. Inaoka, T.; Kosaku, T.; Yada, H.; Yoshida, M,; Ochi, K. (2004). RNA polymerase mutation activates the production of a dormant antibiotic 3,3'-neotrehalosadiamine via an autoinduction mechanism in Bacillus subtilis. J. Biol. Chem., 279, 3885-3892.

8. Katz, E.; Goss, W.A. (1958). Controlled biosynthesis of actinomycin with sarcosine. J. Biochem., 73, 458-465.

9. Kurosawa, K.; Bui, V.P.; Van, E.J.L.; Willis, L.B.; Lessard, P.A.; Ghiviriga, I.; Sambandan, T.G.; Rha, C.K.; Sinskey, A.J, (2006). Characterization of Streptomyces MITKK-103, a newly isolated actinomycin $\mathrm{X}_{2}$-producer. Appl. Microbiol. Biotechnol., 72, 145-154.

10. Shima, J.; Hesketh, A.; Okamato, S.; Kawamoto, S.; Ochi, K. (1996). Induction of actinorhodin production by rps $L$ mutations that confer streptomycin resistance in S. lividans and S. coelicolor A3(2). $J$. Bacteriol., 178, 7276-7284.

11. Shirling, E.B.; Gottlieb, D. (1966). Methods for characterization of Streptomyces species. Int. J. Syst. Bacteriol., 16, 313-340. 